\title{
Why Do Roma Migrate? A Critical Analysis of Academic Silence in Polish Scholarship
}

\section{Kamila Fiałkowska}

k.fialkowska@uw.edu.pl

Centre of Migration Research, University of Warsaw

ORCID: https://orcid.org/0000-0002-1473-9987

Kamila Fiałkowska, $\mathrm{PhD}$, is a researcher at the Centre of Migration Research, University of Warsaw. She has worked on various projects regarding migration from Poland. Currently, she is involved with a research project on the migration of Polish Roma. Her research interests revolve around gender relations in migratory settings, masculinity studies, family relations, and the construction of national and gender identities.

\section{Michał P. Garapich}

m.garapich@uw.edu.pl

Centre of Migration Research, University of Warsaw

ORCID: https://orcid.org/0000-0003-0248-6780

Michał P. Garapich, PhD, is a social anthropologist, specializing in the issues of migration, ethnicity, nationalism, multiculturalism, social resistance, homelessness, and migration from Poland. His $\mathrm{PhD}$ (Jagiellonian University, Kraków) focused on the political and symbolic dimensions of the relationship between different waves and groups of Polish migrants in the UK and Italy, the practices of the de-territorialized nation-state, power relations within diasporic/ethnic associations, and negotiations of ethnicity. At the moment his work focuses on the migration of Polish Roma.

\section{Elżbieta Mirga-Wójtowicz}

\section{emirga@interia.pl}

Centre of Migration Research, University of Warsaw

ORCID: https://orcid.org/0000-0002-3215-7825

Elżbieta Mirga-Wójtowicz is a $\mathrm{PhD}$ candidate at the Institute of Political Science at the Pedagogical University in Kraków. She has been a trainee at the European Commission in the Department of Employment Social Affairs and Equal Opportunities (2005); is an alumna of the Roma Access Programs at the CEU (2006); and since 2007 is a lecturer at the Pedagogical University in Kraków. Since 2007 she works in Malopolska Voivodeship in Krakow in the field of national and ethnic minorities. At the moment her work focuses on ethnic mobilization and the migration of Polish Roma. 


\section{Abstract}

The article discusses the case of academic silence with regards to the migration of Roma from Poland - both in Polish Romani studies and in migration studies. The absence of Romani migration in migration research in Poland is contrasted with the absence of the subject of migration in Romani studies, offering a glimpse into fundamental assumptions, and politically and ideologically determined paradigms within both areas. Paradoxically, the group associated in the social imaginary with mobility is absent in migration studies in Poland. Quite surprisingly, Polish Roma are static and immobilized in Polish Romani studies. The aim of this paper is to critically explore this particular type of discursive silence and how it impacts migration and Romani studies.

\section{Keywords}

- Silence

- Migration research

- Migration of Roma from Poland

- Romani studies 


\section{Introduction ${ }^{[1]}$}

Quite a lot has been written already on silence, pause, or non-speech as elements of social communication. From the perspective of critical discourse analysis, the idea of silence being on equal footing with the spoken word is an integral part of social communication (van Dijk 2008). This article tackles a specific kind of silence in scientific discourse connecting two distinct spheres of social sciences in Poland: migration research and studies on Polish Roma. In recent decades there has been a rise in academic interest, publications, social policy focus, and public attention in both domains, particularly in the context of the enlargement of the European Union (EU) and in freedom of movement within the EU. Research on migration from Poland, especially since 2004 and the massive out-migration to Great Britain following the full opening of the UK labour market, has produced a large number of studies focusing on policies, social and economic integration, education, transnational living, among many other topics, including on the sending and receiving end of this migration phenomena (cf. Burrell 2009; Duszczyk and Lesińska 2009; White, et al. 2018). The website run by the School of Slavonic and East European Studies at University College London tracking publications on migration from Poland informs more than 500 different publications. Among that tsunami of texts, only one addresses the case of Polish Roma, though from a comparative perspective and based on a very small sample (Staniewicz 2011). Acton and Ingmire (2012) offer another glimpse into the lives of migrating Polish Roma in the early 1990s.

Since the publication of seminal works by the main Polish specialists in Roma studies almost a quarter of century ago (Ficowski 1986; Mirga and Mróz 1994; Bartosz 1994), attention has been directed to issues related to social policy in the context of both government (Kwadrans 2008; Mirga-Wójtowicz 2013; Witkowski 2016) and EU assistance to Roma (Krzyżowski and Kowarska 2007; TalewiczKwiatkowska 2013; Szewczyk 2016). Importantly, the EU agenda on integrating the Roma is facilitated by the persistent inequality between new and old EU member states and the ensuing political and social struggles in post-enlargement Europe, thereby making the issue of Roma migrations even more salient (Piemontese and Magazzini 2019). Silence about Roma migrations in Polish ethnographic studies, however, seems to be the symptom of a methodological and theoretical impasse to move along with the Roma themselves - following them where they went, in vast numbers, in the last 30 years - to Germany, Great Britain, or Sweden.

This article aims to answer why this is the case, which will allow us to critically assess assumptions lying behind the theoretical and methodological paradigms governing the development of both migration studies and reflections on the Roma minority in Poland. What we aim to do is to demonstrate how academic discourse produces certain areas of knowledge regarding social processes at hand, and is able to silence the quiet reproduction of assumptions and ideologically loaded stereotypes relating to both

1 This research was made possible with the support of the Polish National Science Centre, Grant Polonez "Continuity or Change Anthropological Analysis of Polish Roma Migration Paths to Great Britain," Grant No. 2015/19/P/HS6/04125. The project also has received funding from the European Union's Horizon 2020 research and innovation programme under Marie Skłodowska-Curie Grant Agreement No. 665778. 
migration processes and Roma. We argue here that behind the academic silence lies a set of cultural assumptions that social sciences, the state, and political discourse reproduce in order to naturalize the imagined national community (Anderson 2006), and to fix and immobilize the place of the significant Other in its realm. In the process of ongoing sociocultural change related to increased immigration to Poland (cf. Górny and Śleszyński 2019), this set of assumptions constructs the supposed ("white") homogeneity of Poland in a normative manner.

Methodologically, this article is a literature-based analysis of Polish migration and Romani studies, and analyses theoretical and conceptual reasons for silence at the point of their intersection - the migration of Polish Roma. It is, as well, grounded in our observations, which come out of an extensive ethnographic study focused on the migration of Polish Roma, conducted in various locations in Poland and the UK during 2016 to 2018 (Fiałkowska, Garapich, and Mirga-Wójtowicz 2019). The article first constructs our view on various reasons behind social, cultural, and academic silencing of Roma, and the ways in which this silencing occurs. It then places these analyses within two specific contexts of scientific knowledge production in Poland and argues that the silencing of Roma in both fields stems from the ideological, often nationalistic and anthropologically orthodox paradigms in which they are rooted, mostly connected with Polish nationalism and a new, postwar ethnic homogeneity. We then explain these omissions through demonstrating connections between various biases that these academic fields suffer from. As such, the article is an invitation to scholars to explore critically not just the field in which they study but the assumptions behind certain politics of research in contemporary academia. In that sense, as Michael Stewart mentioned in a slightly different context (1997), research on Roma is not only about Roma themselves but about the majority society - in this case, Polish.

\section{Silencing the Roma}

Silence as a lack of voice seems difficult to articulate. A symbol of a lack of something, silence paradoxically allows us to demonstrate also a lack of presence (Branach-Kallas 2006, 149). In Western culture, silence is usually associated with lack of power and agency, surrender and passivity - to talk is to be present, being able to influence things in the field of power. As noted by Agnieszka Kościańska $(2009,59)$ gender-related research often equates agency with visible and hearable forms of resistance and, eventually, actions free from social and/or religious constraints. Silence, however, is also a mean of agency, nonverbal form of expression, chosen by, for example, subordinated groups. From the perspective of such groups, it is used strategically to keep something hidden from others (Bollnow 1982). From the feminist or post-colonial perspective, silence is, however, usually associated with oppression based on often intersecting categories like social class, gender, poverty, colour, etc., and not necessarily with lack of speaking. To "emerge from silence into speech" (hooks 2015,23) does not therefore mean simply to talk, but to make the speech heard.

However, the way hegemony controls and dictates discourse conditions means that the weaker side, in order to be heard, has to play by the rules of the powerful, since it is they who define acceptable forms of voice taking and control the perimeters of acceptable discourse (van Dijk 2008). This cultural domination over the silenced weaker side comes across in the use of language, too, as it, in the Bourdieusian sense, reproduces the habitus of the dominant classes, with higher value placed on written sources than 
oral ones. In this context Romani language(s) is seen as not sophisticated enough by the majority society, what places them at the margins of the "proper" cultural production and makes the stereotypes persistent (Hancock 2010).

Despite existing within unequal power relations, silence is not only a sign of passive subordination of those who do not talk. In restrictive conditions, where freedom of expression and the voicing of dissent can be limited, people can resort to other forms of articulation. Sometimes, it may be that silence is the only way to express oneself, a choice driven by a desire to protect oneself or the group (Branach-Kallas 2006, 161), and the right to remain silent is a protection of the weak (Bollnow 1982, 2). In a similar view, James Scott (1990) argues that in order to maintain a margin of individual or group autonomy and an ability to contest power relations and avoid retaliation, the dominated groups can "hide" or "obscure" their voice, which results in cultural "hidden transcripts." These quiet acts of resistance may be a dialogue with one's equals, to let off steam and establish a common understanding with those who understand: the "dialogue - the sharing of speech and recognition - took place not between mother and child or mother and male authority figure but among black women" (hooks 2015, 24). To change the direction of speech and talk among equals toward those who are doing the silencing and promoting their own agenda, to talk about the things that have been unspoken, means breaking the taboo by criticizing their own communities. Raising gender issues over racial and ethnic issues was particularly challenging in the Black feminist movement but also for Romani feminists (Crenshaw 1995; Biţu and Vincze 2012; Oprea 2012; Corradi 2017; Aiello et al. 2019).

In academia, silence historically concerned the lack of Romani voices or an inability to listen to those we talk or write about. Roma still lack, for example, a full recognition of their history in mainstream European historical discourse as well as in researchers of Roma origin (Bartosz 1994; Mirga and Mróz 1994; Acton 1997; Mirga-Kruszelnicka 2018). The ongoing paradigm shift in Romani studies (Ryder 2018 , 92) means that we are seeing an increase in "insider" accounts, challenging - though not without controversy - the hegemony of non-Romani scholars (Corradi 2017). The inclusion and participation of scholars of Roma origin in the production of knowledge and public discourse about Roma, therefore, brings a decisive empowerment to those who have been and still are neglected, silenced, and omitted as those who have for centuries been spoken about by others.

\section{People without History and Future}

Quite a lot has been written on the mythology of the stereotypical representation of the Roma in European history (Trumpener 1992; Acton 1997; Matras 2013). Alaina Lemon (2000,4) argues that it is still hard for dominant groups to accept that Roma not only see themselves as Roma, but identify through other categories, too, including national belonging, ties with their local area, or religious affiliation. Connecting the silence of Roma and the academic interpretation of it, Sławomir Kapralski (2016, 186, translation by the authors) writes:

In the until recently prevailing ethnographic depictions, Romani communities were most often presented as groups whose identity is expressed through a reproduction of a timeless 
cultural idiom, as living in an "eternal present," not bothered by the past or future, and in general careless about past events - either because the past wasn't worth any interest, or because of the specific demands of the Romani culture. This silence was treated as a feature of people who do not possess any idea of history or memory, sustaining their identity through keeping static cultural values and remaining inattentive to the flow of time and unchanged by it.

The construction of Roma as a timeless people "without history" (Trumpener 1992, 861) has had an important theoretical and methodological outcome in narrowing the analytical and empirical scope to Roma only, to focus only on their bounded cultural ecosystem of economic and cultural relations within a settlement or a group (cf. Kapralski 2018, 469), while removing them from the wider sociopolitical context. Writing on Polish Roma, Mróz and Mirga (1994) emphasize that Romani history is a non-Romani projection, stemming from the fact that the nomadic, non-territorial populations were a "testing ground" for the disciplining and the oppressive strategies of governance by modern nation-states. In the study of history this is understood as a competition between "invented traditions" (Hobsbawm and Ranger 1983) through which modern nationalisms legitimize the process of homogenizing their diverse populations along the capitalist logic of the production of homogenous nations (Gellner 1991). Roma, along with many other minorities, minority cultures, or low-status groups, could not find their place, and were evicted from grand narratives. According to Kapralski (1997, 271), the "peculiar Eastern/Central European version of nationalism," with its emphasis on a commonly shared culture, language, ethnicity, and religion, adds to the potential exclusion of Roma from the community of co-nationals, turning them instead into second-class citizens. As he argues (2016), this is the reason behind an incredible asymmetry of power between Roma and the state - that is, the range of oppressive tools at the state's disposal (policing, control, identification, dispersal, mobility restrictions, slavery, and genocides) vis-à-vis a weak, numerically small, economically disadvantaged group. As Stewart $(1997,4)$ rhetorically asks: What was so dangerous about this group that for the last 500 years, states have used all their might to control or eliminate them? At the root of the academic silence on certain aspects of contemporary Roma lives, in the case we describe, lies a construction of Roma as a people fundamentally different, without history and thus without a future as well, without an anchor in physical and social space. For migration studies this is a key dimension, as physical movement give space a meaning and significance (Malkki 1997; Turner and Turner 2011). Spatial movement helps to "name" the place on the continuum between the fundamental cultural opposites of "here and there," "familiar and unfamiliar," and "inside and outside" (Lévi-Strauss 1955; Helms 1988), hence a group that names things in different ways or has a different "attachment" to a territory migrates differently, therefore requiring different analytical tools. The stereotype of the eternal wanderer who does not belong - because being a "wanderer" is how he/she naturally is - helps to deprive such as person of their national belonging, fatherland, or territory, and hence denies them a place in society. But, as Zbigniew Benedyktowicz remarks, stereotypes actually tell us more about those who construct them than those whom they attempt to describe $(2000,83)$, hence this stereotype serves to validate a moral worldview that values a sedentary, rooted existence, and reinforces the "container" model of society. In other words, the idiom of the eternal Roma wanderer serves as a useful fiction to justify the nationalist discourse of people anchored and eternally attached to one place, one country, and one nation only. As Michael Stewart rather ironically paraphrases Voltaire, even if the Roma did not exist, modern nationalism would have to invent them $(1997,238)$. 
For migration studies, this sedentary bias seems to be one of the outcomes of that equation of territory and space, informed by a particular cultural notion of the kinds of people who ought to inhabit them. As Stephen Castles explains (2010), such bias is a theoretical assumption that naturalizes sedentary lifestyles, mainly rural ones, at the expense of a pathologization of mobility. From the perspective of a sending country, like Poland, such a construction of migration engenders moral panic, like that related to the increased emigration of women and the anticipated crisis of families and shifting gender relations (cf. Urbańska 2015). Migrating Roma from Central and Eastern Europe caused another kind of moral panic (see Clark and Campbell 2000) concerning the securitization of EU migration and border policies (van Baar, Ivasiuc, and Kreide 2018) and its welfarist and emergency-driven approach (Piemontese and Magazzini 2019).

Further, immigration and integration policies also strengthen this stance on migration and its social consequences, constructing it as a sort of aberration that has to be dealt with. This view has its roots in the nationalist, hegemonic naturalization of social life, in which a vision of populations being divided into neat territory groups is transported from the domain of historical peculiarity to that of biological necessity. In this model, migrations - along with all spaces of intercultural boundary blurring, borderlands, and conceptual grey areas of the multiplicity of belonging and identities are an unwanted distortion, a stain on clean sheets of national purity and a dangerous empirical falsification of "timeless" nationalist ideas. This "metaphysics of sedentary life," as Lisa Malkki (1997) refers to it, constructs a biological link between people and land, a link severed in the case of nomads and migrants, or in the highly mobile and diverse settings of modern cities. As scholars note, in the case of Roma, sedentary bias plays a decisive role in historical and ethnographic exhibitions across Poland and Romania (Hasdeu 2008; Vermeersch 2008).

\section{Migrants and the Political Power of Terminology}

In this section we follow the genesis of and try to reconstruct the reasons behind this state of affairs, focusing on migration studies in Poland. Broadly speaking, this academic domain encompasses the history of migration from Poland, diaspora research, and, in particular, studies on post-EU accession migration. Historians looking at emigration restrictions during communist times, such as Dariusz Stola in his seminal work (2010), mention the practice of giving Roma "one way passports," but do not delve deeper into numerous instances of Roma emigration due to anti-Roma pogroms, such as in Oświęcim or Konin in 1981 (Mirga and Mróz 1994; Kapralski 2009). An exception to this rule that is little known in Poland is the work of Ignacy-Marek Kamiński (1980) - published in Sweden - whose PhD research focused on several families of Polish Kalderasha and their sensational journey of migration from Poland to Sweden at the beginning of the 1970s. But despite the highly sophisticated organizational aspects of that migration, their story did not join the other legends about spectacular escapes from the communist "heaven" about which historians often write (Stola 2010).

Lack of critical scholarly focus on Roma migrations in Poland is odd as well in light of the fact that the topic has been hotly discussed in the media, with various levels of intensity since the early 1990s. The 1991 anti-Roma riot in Mława attracted the attention of scholars at the time (Giza-Poleszczuk and 
Poleszczuk 2001; Kapralski 2016), who focused on the political, social, and economic crisis in the period of transformation that severely hit Mława and other towns. The key finding of the study on the roots of anti-Roma violence pointed to the migration of local Roma. In a suddenly impoverished town, they accumulated considerable wealth and local influence through a used car trade, with German imports. But when and how this migratory practice started, what the transnational connections were with Germany, and, most importantly, how it affected the subsequent mass emigration of Roma from Mława, among other destinations, to England (Horton and Grayson 2008, 9), the authors do not elaborate, nor do these topics attract further attention.

The main media storm began in 1995 when Polish newspapers covered cases of Polish Roma seeking political asylum in Great Britain. The underlying theme in these media reports is the notion of separateness and the distinction between ethnic Poles, who seek work or are tourists, and Roma, who abuse the system and thus put the reputation of the former in jeopardy, along with accusations of unjust claims that Roma were being mistreated in Poland. Crucially, at the very same time throughout the 1990s until the enlargement of the EU, hundreds of thousands of Polish migrants were navigating hostile mobility regimes, working in the shadow economy, and living with illegal status, some even pretending to be Roma while seeking asylum (Morawska 2001; Garapich 2008; Garapich 2016). Political attention, however, turned on a few thousand Roma, who by definition were constructed as a problem. The letter sent from UK prime minister Tony Blair to Jerzy Buzek, the Polish prime minister, in September 1999, is highly symbolic in this context. Blair complained openly that a "thousand Roma" with dependents were a threat and were abusing the system, but at the same time observed that Britain welcomed the fact that "around 150,000 Poles visit this country each year, the vast majority as genuine tourists, students or [for] business." Blair noted that "we welcome them warmly," conveniently omitting the fact that in the runup to Poland's accession to the EU in 2004, Poles were the group of migrants most strongly associated with breaching immigration rules by the UK Home Office (Garapich 2016). The neoliberal economics behind this distinction could not be more obvious. Conveniently turning a blind eye to non-Romani Poles working in the shadow economy, maintaining the neoliberal economic logic, is one thing; asking for state protection is quite another. The "right" kind of mobility is one in which there will be a focus on work, productivity, and subsequent exploitation, whereas the "wrong" kind of mobility is one in which protection will be sought from human right abuses and discrimination.

From an anthropological perspective, the exclusion of Roma migrations from overall reflections on mobility from Poland is understandable. The early attention of scholars was focused on the migration of ethnic Poles, and hence a clear process of ethnic categorization took place - despite the fact that the same regions witnessed the emigration of Jews, Ukrainians, and Lithuanians. The opus magnum and founding work of Polish migration scholarship, by Florian Znaniecki, after all is entitled The Polish Peasant in Europe and America. We could explain this as an outcome of the lack of Polish statehood until 1918, but this tendency for exclusion continues until today.

Stemming from a specific migration culture conceptualized in a historiosophy of Polish emigration, mobilities in that construction are a part of a wider plan of national community building. In that grand narrative, emigrations in Polish history are structured and morally hierarchized. Polish emigrants were thus morally judged in relation to their political activism aimed at the rebirth of the Polish state, with an 
important exclusion of movement based on class, gender, or freedom from oppressive post-feudal social relations. This moral hierarchization thus places emigrants who left Poland for "political" reasons above those whose reasons were solely "economical." Mary Erdmans refers to this grand narrative as a particular feature of Polish migration culture's "moral issue" (1992), in which the collective loss is weighted against individual gain. The only moral justification for leaving would be to benefit the political nationalist goal - hence the symbolic place of various emigrant poets, revolutionaries, activists, and politicians fighting for the Polish state through the nineteenth century, about whom generations of Polish children are taught in schools (Micińska 2004). Despite this, in fact, emigration from Poland throughout this period has been mainly that of peasantry escaping economic hardship and post-feudal social conditions (Praszałowicz, Makowski, and Zięba 2004; Walaszek 1988), and it was the political diaspora that gained its place in the imagination of dominant nationalists. Symptomatic of this approach that the role emigration from Poland plays in the nationalistic narrative is a position of a student of Znaniecki, sociologist Jerzy Zubrzycki, whose generalized vision depicts a historical trajectory of Polish emigration - in his own terminology from "peasants to soldiers" (1988). Peasants who emigrated "for bread" have, due to macro-political events and their own desire for progress, been elevated to the status of soldiers fighting for an independent Polish state - through joining the army of emigrants to fight in two world wars, or participating in numerous diasporic fraternities and organizations that sustain the national - and religious - core of the nation's citizens scattered abroad.

Unsurprisingly, the emigration of women, minorities, Jews, and peasants escaping the hardships of postfeudal Polish society of the nineteenth century is discursively silenced (cf. Horolets and Bielecka-Prus 2017). In the eyes of nationalists, women were subjected to and following men, and the emigration of Polish Jews in the interwar period was seen as a positive development, as opposed to the emigration of Polish peasants, which was seen as endangering the national fabric and jeopardizing the "Polonization" of Polish lands. In this nationalist model, minorities are a systemic anomaly that has to be dealt with, either in radical form through physical expulsion or academically through discursive silencing. One of the outcomes of this position in relation to Polish postwar society was a continuous normalizing of ethnic and religious homogeneity. Normalizing here relates to the treatment of homogeneity as a natural and desirable state of affairs - how Polish society should look like. Minorities are to some extent accepted, in principle only as an exception, and are analytically evicted to the domain of "ethnic" or "minorities" studies, which treat them as separate from and marginal to the whole body of Polish society.

Roma migrations from Poland do not fit that dominant discourse. Constructed in an essentialist way as characteristic of Roma, their mobility cannot be framed through external determinants, since Roma migrate because of "who they are," due to some internal deterministic drive, not because of the world they live in. Despite living in Poland for half a millennia, Roma were not treated through the same metaphysical sedentary lens, and therefore, in fact, their mobilities have endangered the nationalist project. Despite that only some Roma in Poland lead a nomadic lifestyle, with other groups living in the same villages for more than two centuries (Ficowski 1986; Bartosz 1994), Roma are mysteriously excluded from these narratives of emigration, moral worth, and nationalist projections of the purity of Polish lands. They also did not fit into the moral obligation to create formal and active Polish diasporic groups whose task of building "Poland abroad" was meant to extend the struggle for statehood and nationalistic ideas while outside the sacred sphere of the territory. Furthermore, their collective claims 
for political asylum were met with such media hostility and political backlash precisely because being a "political" refugee was reserved for Polish "freedom fighters." By becoming "political," Roma have transgressed a subtle cultural idiom in Polish migration culture, in which to be oppressed meant to be oppressed by alien hostile regimes (or internal traitors), not by your own neighbors, racist and discriminatory discourses, or state. Since regaining its independence in 1918 from the post-Second World War communist regime, the approach of the Polish state was to engage and act with but also influence its diaspora, which it saw as an element of soft power, or as potential lobbying groups over foreign governments or actors in international politics (Kicinger 2005; Lesińska 2019). Here again, Polish Roma did not find their space. In the vast and long history of diaspora engagement policy that Poland has been engaged in, the Polish Roma are absent, silenced.

The international, and especially pendulum, migration strategies of Poles living in the post-transformation period of 1989 were largely livelihood strategies. As the most important sociological analysis looking at Poles' international mobility shows (Jaźwińska and Okólski 2001), this circular strategy of “incomplete migration" was partially the outcome of a mismatch between the rapid industrialization of communist Poland and under-urbanisation, forcing many rural inhabitants to work in factories but live in their own villages. The unemployment rate was highest among this relatively low-skilled group of rural-urban commuters, whose livelihood strategy was to go to the West, taking advantage of lifted visa requirements (Morokvasic 2004). This strategy fits well with what we learned about the migration of Polish Roma in the very same period. This is confirmed in the reports from Roma NGOs (Lesińska 2014) about mass migrations of Polish Roma, including some observations that there are towns or villages where almost all Roma have left, and others where more than half have left.

Here again, their migrations did not fit the theoretical framework dividing migrations according to motivations - economic versus political. In fact, as we have seen, Roma have become a political problem themselves. Their migrations prior to 2004 could not be categorically classified as political or economic, even if their asylum applications referred to rising racism and discrimination (Acton and Ingmire 2012). From Roma narratives collected during our study (Fiałkowska, Garapich, Mirga-Wójtowicz 2019), it is clear that the decision had also to do with a personal sense of security, perspectives regarding education for their children, more opportunities, and finally being able to live in a country where you are not an outcast. This is highly problematic, given that Roma, along with vast sections of the Polish working class and rural population, were the first victims of economic transformation. What was clear for anthropologists at the time (Nagengast 1991; Buchowski 2004; Dunn 2004; Rakowski 2009), as is widely accepted today, the transition to the new system brought enormous social costs. These costs were cushioned by the largely irregular and informal nature of Polish international mobility and participation in the labour markets (Morawska 2001; Garapich 2016), or in the case of Roma, by confronting these changes, highlighting their increased fear for their personal security, and the threat of violence in the new conditions. The transition period was followed with the rise of antigypsyism and local conflicts, as a result of which Polish Roma sought asylum in the West (Matras 2000, 37-8). Their migration generated a hysterical response - from both sides. The Polish prime minister, in response to Tony Blair, assured his British counterpart that Roma were not discriminated against in Poland, as if the reports from Roma rights organizations of the time did not matter. The economycentred logic of migration scholarship is another reason why scholars did not focus on Roma, instead turning their attention to the fiscal and labour market outcomes of the migration and the issues of supply 
and demand that came out of the growing interconnectedness of East and West (Kaczmarczyk and Okólski 2008; Drinkwater, Eade, and Garapich 2009; Okólski and Salt 2014). In this approach, macrostructural determinants did not fit the essentialist perception of the migrating Roma, who were allegedly migrating due to some cultural or genetic features, not due to structural and economic factors.

\section{Roma in Poland: Immobile Nomads}

If the reasons behind the silencing of Polish Roma mobilities by Polish migration scholarship are now a little clearer, then what about the other field - Polish Romani studies? Given the essentialist notion of Roma, the total lack of interest in Romani studies regarding where, when, and how Roma have migrated in last 30 years is quite peculiar. If mobility is their inalienable cultural feature, why has no one looked at the transnational dimension of their lives, and how their migratory history relates to Polish migration movements, and affects their diverse cultures, meaning-making practices, identity, economic relations, and the like?

The silence in this domain reveals a certain paradox in Polish Romani studies. On the one hand, it treats Roma mobility as one of the key cultural features of Roma that connects them through generations, bridging various distinct Roma groups; yet on the other hand, it fails to make migration/mobility an element of ethnographic inquiry. The highly distinguished academic and activist Adam Bartosz, initiator of the only ethnographic exhibition on Roma in Poland, commented on Romanian Roma migrations, comparing them to the ones some Polish Roma undertook during the 1970s and 1990s, writing: "these situations show an unusual mobility of Gypsies, and a failure in any attempts to curtail their urge to roam" (Bartosz 2007, 151).

It seems that Romani studies in Poland are also victims of sedentary bias, and the analysis within this field remains spatially and socially bounded to the world of the Romani settlement in a given location, thus dismissing their international mobility as irrelevant or too ambiguous to contemplate in ways other than the stereotypical notion of their "urge to roam." In other words, for such a seemingly categorically mobile group, the Roma in Polish ethnography seem surprisingly immobile and spatially fixed. Their experiences abroad, their migration networks, the effect of their education in non-Polish schools, their social remittances, changes to their identity due to increased interactions with Roma from different groups and national backgrounds, and many other consequences of international mobility, which are the bread and butter of migration scholarship, are relegated to academic silence.

As we document in our report (Fiałkowska, Garapich, and Mirga-Wójtowicz 2018), intensive migrations in the 1990s have had an enormous impact on Polish Roma. One of the key testimonies comes from the accounts of a Gadjo, Romani-speaking teacher and writer, Jacek Milewski (2008; 2013), whose selection of short stories is probably the most contemporary, vivid, and accurate account of Polish Roma lives. In these stories, migrations and their impacts on Roma feature constantly, mainly as an event of a massive family disruption, the degradation of kinship ties, the negative outcomes of young Roma coming into contact with modern consumer society in the West, or the increased mobility of Roma from other countries to Poland. These stories align well with what transpires from our research - Roma, using Facebook Live or Skype, talk over their kitchen tables to their kin in Germany, Ireland, Canada, and Great Britain. It is a shame that these 
conversations did not make it into ethnographic accounts within Polish Romani studies, which in light of the veritable boom in interest by European scholars in Romani mobilities is further surprising.

The paradox that immobilizes populations regarded as essentially mobile can be framed as a theoretical residue of an orthodox anthropological paradigm, one that equates culture, people, and territory. In their seminal article on how early anthropologists conceptualized culture, Akhil Gupta and James Ferguson (1997) explain how the bounded notion of the "people" confined in one spatial unit of "the village" allowed early scholars to cut off any form of hybridization, cultural diffusion, and change. In order to conceptualize and empirically "capture" the culture in its "pure" and "undisturbed" state, anthropologists needed to assume that locals were immobile and had no meaningful contacts with the outside world, and that their spatially bounded "way of life" remained a closed cultural ecosystem. As James Clifford argues (1988), seeing mobility, travel, and expansion as predominantly Western privileges was also one of the features of the political dominance of Western anthropology. In this bias, traditional societies did not travel or wander to learn about others, and their mental horizons were bounded by spatial limitations. Only Western anthropologists had the privilege to travel in order to "discover." As Gupta and Ferguson emphasize, the growth in migration globally increasingly has posed a theoretical and methodological challenge to these perspectives, as the "native" came to anthropologists' doorsteps. In our case, it seems the Roma have left Polish ethnographers' doorsteps, while being unable to see and acknowledge their departure.

The main problem with regards to Polish Romani studies is that bounded concepts of their culture have led to an inability to see their migrations - or any aspect of their lives - within a larger comparative and structural framework. These same bounded concepts stem from the artificial and ideological removal of Polish Roma from wider processes that the whole of Polish society underwent. It is not rare among Polish scholars to reproduce the old clichés related to the stereotype of the eternal wanderer. The distinguished anthropologist Ewa Nowicka, for example, notes that the use by Roma of the newly gained freedom of movement within the EU makes them a "model European," for whom "mobility does not present any problem of psychological nature since space isn't important for their fulfillment of social roles of personal identity ... unbounded by their attachment to one place, they freely roam around Europe" (Nowicka 2007, 127). Besides the fact that Roma "roam" around Europe on its social and economic margins, subject to increased racialization and politicization of their mobility through evictions, the destruction of their settlements, forced removal, and state-sanctioned racism (Sigona 2005; Sigona and Theran 2009; O'Nions 2011; Nacu 2012), the danger in the assumption voiced by Nowicka is to discursively deny them a firm place in a given locality or nation. This is not about directing criticism toward what may be a very broad generalization, but rather an acknowledgement that notions and concepts have political weight, for which real people pay a very real price.

\section{Conclusion}

Our diagnosis does not refer to only what has been said but also why certain things were said, and others omitted or relegated to the sphere of academic silence. By definition, the sphere of silence is larger than that of discourse; the key, then, for our understanding of scholarship development is to account for 
the historical and political dimensions within which the scholarship on migrations and Polish Roma is reproduced. It is at the intersection of these two domains that we are able to see the three-dimensional picture of both the structural and individual dimensions of human mobility, in our case that of Polish Roma, and crucially to place it within a wider analysis of the changes that Polish society is undergoing. Both areas are heavily weighted with assumptions and research paradigms into which Roma mobility does not fit, and which sometimes exclude any attention to Roma mobilities in ways that might construct them as different, unusual, and politically and culturally ambiguous, removing them from the analytical tools at scholars' disposal.

In the process of knowledge production on Roma, issues that were most vital to their survival in a hostile environment - the ability to adapt, and to negotiate their place-making while at the same time ensuring the continuity of their traditions - were paradoxically delegated to the sphere of academic silence. This not only happened at the expense of the voice of the Polish Roma who migrated and whose everyday dilemmas did not differ substantially from those of other migrating groups (see Fiałkowska, Garapich, and Mirga-Wójtowicz 2018), but it also contributed to the political exclusion of Roma in the Polish social landscape. In this perspective, academic silence is not just a mechanism of voice deprivation; it is a powerful tool of expulsion from the intellectual, social, and physical community. As mentioned previously, the best example with reference to Polish migration issues is the diaspora engagement policy, which the Polish state uses to assist various social and cultural initiatives among its wide global diaspora, but also as a mechanism for political pressure, through funding particular organizations and excluding others. Roma issues - despite the considerable numbers of Roma living in Germany, Sweden, and the UK - are never part of Polish discourse on its diaspora.

Not only are these comments to be conveyed as a critical assessment for its own sake, they are also to be considered an invitation for a discussion involving all social scientists, regardless of the level of their interest in the migration of Roma. The fact that we are discussing a numerically small group should not matter: the themes and issues raised here are of wider academic, social, and moral significance. The reduction of the number of Polish Roma in Polish towns and villages contributes to the reduction of Poland's ethnic diversity, and this further normalizes the ideological assumption of the necessity of a nationalist ideal of ethnic and cultural homogeneity. The silence we talk about has therefore a powerful political outcome. Polish society is undergoing a rapid change in terms of becoming a country of immigration, where new ethnic minorities emerge, posing a challenge to Poland's nationalist ideas. The silencing of Roma - in terms of scholarship as well as public acknowledgment - is a normative and hegemonic attempt to construct that homogeneity as a historical necessity, "the natural way things are." In this normative framework, national and ethnic minorities are not treated as an integral part of the social fabric but as a problem, an anomaly, and an issue that requires correction or oppressive actions of the state apparatus. In that sense, the way Polish scholars have silenced migrating Roma will be reproduced with regards to other minorities, relegating their status to bounded, fixed, essentialist entities that are regarded as exotic, alien, and non-Polish "in nature." Silence is never innocent, but is politically and culturally intertwined with our own understanding of the social world. The time has come for Polish scholarship to include Polish Roma in that wider world. 


\section{References}

Acton, Thomas. 1997. Gypsy Politics and Traveller Identity. Hatfield, UK: University of Hertfordshire Press.

Acton, Thomas, and Sylvia Ingmire. 2012. "I nikt nie rzuca w nie kamieniami: Romscy imigranci z Polski i ich wkład do polityki Romów/Cyganów/Wędrowców w Zjednoczonym Królestwie” [And nobody throws stones at them: Polish Roma migrants and their contribution to Roma, Gypsy, Traveller politics in the United Kingdom]. Studia Romologica 5: 77-95.

Aiello, Emilia, Jelen Amador-López, Adriadna Munté-Pascual, and Teresa Sordé-Martí. 2019. “Grassroots Roma Women Organizing for Social Change: A Study of the Impact of 'Roma Women Student Gatherings."' Sustainability 11 (15): 4,054.

Anderson, Benedict. 2006. Imagined Communities: Reflections on the Origin and Spread of Nationalism. London: Verso. van Baar, Huub, Ana Ivasiuc, and Regina Kreide. 2019. “The European Roma and Their Securitization: Contexts, Junctures, Challenges." In The Securitization of the Roma in Europe, edited by Huub van Baar, Ana Ivasiuc, and Regina Kreide, 1-25. London: Palgrave Macmillan.

Bartosz, Adam. 2004. Nie bój się Cygana [Don’t be afraid of a Gypsy]. Sejny, Poland: Pogranicze.

. 2007. "Cyganie/Romowie: Ostatni wędrowcy Europy" [Gypsy/Roma: The last wanderers in Europe]. In Romowie w Polsce i Europie [Roma in Poland and in Europe], edited by Piotr Borek, 148-57. Kraków: Wydawnictwo Naukowe Akademii Pedagogicznej.

Basch, Linda, Nina Glick Schiller, and Christina Shanton Blanc. 1994. Nations Unbound: Transnational Projects, Postcolonial Predicaments, and Deterritorialized Nation-States. Amsterdam: Gordon and Breach.

hooks, bell. 2015. Talking Back: Thinking Feminist, Thinking Black. London: Routledge.

Benedyktowicz, Zbigniew. 2000. Portrety "obcego": Od stereotypu do symbolu [Portraits of a "stranger": From stereotype to a symbol]. Kraków: Wydawnictwo UJ.

Biţu, Nicoleta, and Enikő Vincze. 2012. “Personal Encounters and Parallel Paths toward Romani Feminism.” Signs: Journal of Women in Culture and Society 38 (1): 44-6.

Bollnow, Otto F. 1982. “On Silence: Findings of Philosophical-Pedagogical Anthropology." Universitas 24 (1): 41-7.

Branach-Kallas, Anna. 2006. "Itineraries of Silence: Female Migrants and Voice/lessness in Selected English Canadian and Quebecois Fiction." Kwartalnik Neofilologiczny 53 (2): 148-65.

Buchowski, Michał. 2004. "Redefining Work in a Local Community in Poland. Transformation and Class, Culture, and Work." In Workers and Narratives of Survival in Europe: The Management of Precariousness at the End of the Twentieth Century, edited by Angela Procoli, 173-96. Albany, NY: State University of New York Press.

Burrell, Kathy. 2009. Polish Migration to the UK in the 'New' European Union: After 2004. Aldershot, UK: Ashgate Publishing.

Castles, Stephen. 2010. “Understanding Global Migration: A Social Transformation Perspective." Journal of Ethnic and Migration Studies 36 (10): 1,565-86.

Clark, Colin, and Elaine Campbell. 2000. “'Gypsy Invasion’: A Critical Analysis of Newspaper Reaction to Czech and Slovak Romani Asylum-Seekers in Britain, 1997.” Romani Studies, 10 (1): 23-47.

Clifford, James. 1988. The Predicament of Culture: Twentieth-Century Ethnography, Literature, and Art. Cambridge, MA: Harvard University Press. 
Cohen, Anthony P. 1985. The Symbolic Construction of Community. London: Open University.

Corradi, Laura. 2017. Gypsy Feminism: Intersectional Politics, Alliances, Gender and Queer Activism. London: Routledge.

Crenshaw, Kimberle. 1995. "Mapping the Margins: Intersectionality, Identity Politics, and Violence Against Women of Color." In Critical Race Theory: The Key Writings that Formed the Movement, edited by Kimberle Crenshaw, Neil Gotanda, Garry Peller, and Kendall Thomas, 357-83. New York, NY: New Press.

Drinkwater, Stephen, John Eade, and Michał P. Garapich. 2009. "Poles Apart?: EU Enlargement and the Labour Market Outcomes of Immigrants in the United Kingdom.” International Migration 47(1): 161-90.

Drużyńska, Jolanta. 2015. Ostatni tabor: Jak władza ludowa zakazała Cyganom wędrowania (The last caravan: How the communist authorities prohibited Gypsy from wandering). Poznań, Poland: Dom Wydawniczy Rebis.

Dunn, Elisabeth C. 2004. Privatizing Poland: Baby Food, Big Business, and the Remaking of Labor. Ithaca, NY: Cornell University Press.

Duszczyk, Maciej, and Magdalena Lesińska. 2009. Współczesne migracje: Dylematy Europy i Polski (Contemporary migrations: Dilemmas of Europe and Poland). Warsaw: Ośrodek Badań nad Migracjami (OBM), University of Warsaw.

Erdmans, Mary P. 1992. “The Social Construction of Emigration as a Moral Issue.” Polish American Studies 49 (1): $7-25$.

Faist, Thomas. 2000. The Volume and Dynamics of International Migration and Transnational Social Spaces. New York, NY: Oxford University Press.

Fiałkowska, Kamila, Michał P. Garapich, and Elżbieta Mirga-Wójtowicz. 2018. Between Tradition and Change: Migration Paths of Polish Roma. Warsaw: Centre for Migration Research, University of Warsaw.

- 2019. "Polish Roma Migrations: Transnationalism and Identity in Anthropological Perspective." Ethnologia Polona 40: 247-76.

Ficowski, Jerzy. 1986. Cyganie na polskich drogach [Gypsies on the Polish road]. Kraków, Poland: Literackie. 1989. Cyganie w Polsce: Dzieje i obyczaje [Gypsies in Poland: History and customs]. Warsaw: Interpress.

Fraser, Angus M. 2001. Dzieje Cyganów [History of the Gypsies]. Warsaw: Państwowy Instytut.

Garapich, Michał P. 2008. “The Migration Industry and Civil Society: Polish Immigrants in the United Kingdom before and after EU Enlargement." Journal of Ethnic and Migration Studies 34 (5): 735-52.

-2016. London's Polish Borders: Transnationalizing Class and Ethnicity among Polish Migrants in London. New York, NY: Columbia University Press.

Gay y Blasco, Paloma. 2008. "Picturing 'Gypsies' Interdisciplinary Approaches to Roma Representation” Third Text 22 (3): 297-303.

Geertz, Clifford. 1983. Local Knowledge: Fact and Law in Comparative Perspective. New York, NY: Basic Book.

Gellner, Ernest. 1991. Narody i nacjonalizm [Nations and nationalism]. Warsaw: Państwowy Instytut.

Giza-Poleszczuk, Anna, and Jan Poleszczuk. 2001. Cyganie i Polacy w Mławie: Konflikt etniczny czy społeczny? [Gypsies and Poles in Mława: Ethnic or social conflict?]. In Trudne sąsiedztwa: Z socjologii konfliktów narodowościowych [Difficult neighborhoods: Sociology of the national conflicts], edited by Anna JasińskaKania, 221-47. Warsaw: Wydawnictwo Naukowe Scholar. 
Glick Schiller, Nina, Linda Basch, and Christina Szanton Blanc. 1995. "From Immigrant to Transmigrant: Theorizing Transnational Migration.” Anthropological Quarterly 68 (1): 48-63.

Grabowska-Lusińska, Izabela, and Marek Okólski. 2009. Emigracja ostatnia? [The ultimate emigration?]. Warsaw: Wydawnictwo Naukowe Scholar.

Grabowska, Izabela, Michał P. Garapich, Ewa Jaźwińska, and Agnieszka Radziwinowiczówna. 2017. Migrants as Agents of Change: Social Remittances in an Enlarged European Union. London: Palgrave Macmillan.

Górny, Agata, and Przemysław Śleszyński. 2019. "Exploring the Spatial Concentration of Foreign Employment in Poland under the Simplified Procedure." Geographia Polonica 92 (3): 331-45.

Gupta, Akhil, and James Ferguson. 1997. "Culture, Power, Place: Ethnography at the End of an Era." In Culture, Power, Place: Explorations in Critical Anthropology, edited by Akhil Gupta and James Ferguson, 1-29. Durham, PA: Durham Press.

Hancock, Ian. 2010. Danger! Educated Gypsy: Selected Essays. Hertfordshire, UK: University of Hertfordshire Press.

Hasdeu, Iulia. 2008. "Imagining the Gypsy Woman: Representations of Roma in Romanian Museum." Third Text 22 (3): 347-57.

Helms, Mary W. 1988. Ulysses' Sail: An Ethnographic Odyssey of Power, Knowledge, and Geographical Distance. Princeton, NJ: Princeton University Press.

Hobsbawm, Eric, and Terence Ranger. 1983. The Invention of Tradition. Cambridge, UK: Cambridge University Press.

Horolets, Anna, and Joanna Bielecka-Prus. 2017. "Strategie wykluczania w reprezentacjach polskiej emigracji na łamach paryskiej 'Kultury' (1947-2000)" [Exclusion strategies in Polish emigration teams in Paris "Culture” [1947-2000]]. In Polskie sprawy: 1945-2015 [Polish affairs: 1945-2015]. Warsaw: Sedno.

Horton, Marion, and John Grayson. 2008. Roma New Migrants: Local Research in the UK and European Contexts. A conference report of Roma New Migrants: A Research and Information Day, Burngreave, UK, 8 March.

Jaźwińska, Ewa, and Marek Okólski. 2001. Ludzie na huśtawce: Migracje międzyperyferiami Polski i Zachodu [People on a swing: Migrations between peripheral regions of Poland and of the West]. Warsaw: Wydawnictwo Naukowe Scholar.

Jordan, Bill, and Frank Düvell. 2002. Irregular Migration: The Dilemmas of Transnational Mobility. Cheltenham, UK: Edward Elgar Publishing.

Kaczmarczyk, Paweł, and Marek Okólski. 2008. "Demographic and Labour-Market Impacts of Migration on Poland.” Oxford Review of Economic Policy 24 (3), 599-624.

Kaminski, Ignacy-Marek. 1980. The State of Ambiguity: Studies of Gypsy Refugees. Gothenburg, Sweden: University of Gothenburg.

Kapralski, Sławomir. 1997. "Identity Building and the Holocaust: Roma Political Nationalism.” Nationalities Papers 25 (2): 269-83.

_ 2009. "Refleksje o pogromach na marginesie wydarzeń w Oświęcimiu w 1981 r” [Reflections on pogroms on the margins of events in Oświęcim in 1981]. Studia Romologica 2: 233-52.

. 2016. “Milczenie, pamięć, tożsamość: Fantazmat ‘Cygana’ i ambiwalencja nowoczesności” [Silence, memory, identity: Phantasm of a Gypsy and ambivalence of modernity]. Ethos: Kwartalnik Instytutu Jana Pawła II 29 (1): 185-202. 
. 2018. "Gender, History, and Roma Identities: From Cultural Determinism to the Long Shadow of the Past." Slovenský národopis 66 (4): 467-86.

Kicinger, Anna. 2005. "Polityka emigracyjna II Rzeczypospolitej” [Migration policy of the Second Polish Republic]. Central European Forum for Migration Research, CEFMR Working Paper 4/2005.

http://www.cefmr.pan.pl/docs/cefmr_wp_2005-04.pdf.

Kościańska, Agnieszka. 2009. Potęga ciszy: Konwersja a rekonstrukcja porządku płci na przykładzie nowego ruchu religijnego Brahma Kumaris [The power of silence: Conversion and reconstruction of gender order on the case of new religious movement of Brahma Kumaris]. Warsaw: Wydawnictwo Uniwersytetu Warszawskiego

Kowarska, Agnieszka J. 2005. Polska Roma: Tradycja inowoczesność [Polska Roma: Tradition and modernity]. Warsaw: Instytut Etnologii i Antropologii Kulturowej (IEiAK), University of Warsaw.

Krzyżowski, Łukasz, and Agnieszka. J. Kowarska. 2007. "Romowie wobec wyzwań nowoczesności” [Roma and the challenges of modernity]. Kultura i Społeczeństwo 51 (4): 220-3.

Kwadrans, Łukasz. 2008. "Edukacja Romów: Studium porównawcze na przykładzie Czech, Polski i Słowacji” [Education of Roma: A comparative study of Czecha, Poland and Slovakia]. Wrocław, Poland: Fundacja Integracji Społecznej PROM, Państwowa Wyższa Szkoła Zawodowa (PWSZ) im. Angelusa Silesiusa.

Lemon, Alaina. 2000. Between Two Fires: Gypsy Performance and Romani Memory from Pushkin to Post-Socialism. London: Duke University Press.

Lévi-Strauss, Claude. 1955. “The Structural Study of Myth.” Journal of American Folklore 68 (270): 428-44.

Lesińska, Magdalena. 2014. Migracje Romów w Europie w przeszłości I obecnie: Ciągłość czy zmiana? [Roma migrations in Europe in the past and currently: Continuity or change?]. In Kwestia romska w kontekście bezpieczeństwa wewnętrznego [Roma issue in the context of internal security], edited by Elżbieta Szyszlak and Tomasz Szyszlak, 195-207. Wrocław: Fundacja Integracji Społecznej Prom.

- 2019. Niełatwe związki: Relacje polityczne między państwem pochodzenia a diaspora - Polska i polska diaspora w okresie przełomu 1989 roku i później. [Complicated relationships: Political relations between the state of origin and the diaspora - Poland and the Polish diaspora in the transition of 1989 and afterwards]. Warszawa: Wydawnictwa Uniwersytetu Warszawskiego.

Malkki, Lisa. 1997. "National Geographic: The Rooting of Peoples and the Territorialization of National Identity among Scholars and Refugees." In Culture, Power, Place: Explorations in Critical Anthropology, edited by Akhil Gupta and James Ferguson, 24-44. Durham and London: Duke University Press.

Matras, Yaron. 2000. "Romani Migrations in the Post-Communist Era: Their Historical and Political Significance." Cambridge Review of International Affairs, 13 (2): 32-50.

_ 2013. "Scholarship and the Politics of Romani Identity: Strategic and Conceptual Issues." RomIdent Working Papers, Paper No. 1, University of Manchester.

Matras, Yaron, and Daniel V. Leggio. 2017. Open Borders, Unlocked Cultures: Romanian Roma Migrants in Western Europe. London: Routledge.

Micińska, Magdalena. 2004. Zdrada, dezercja czy jedyna szansa? Dyskusje wokół tzw. emigracji talentówzziem polskichwdrugiejpołowie XIXw. ina początkuXXw. [Betrayal, dezertion or the only chance?: Discussions around emigration of talents from the Polish territories in the second half of the 19th and beginning of 20th century]. In Migracje i Społeczeństwo [Migration and society] 9, edited by Jan E. Zamojski, 91-109. Warsaw: Neriton.

Milewski, Jacek. 2008. Dym się rozwiewa [The smoke is blowing away]. Poznań, Poland: Zysk i S-ka. 
2013. Chyba za nami nie traficie [You probably will not find us]. Warsaw: WAB.

Mirga, Andrzej, and Lech Mróz. 1994. Cyganie: Odmienność i nietolerancja [Roma: Otherness and intolerance]. Warsaw: Naukowe PWN.

Mirga-Kruszelnicka, Anna. 2018. "Challenging Anti-Gypsyism in Academia: The Role of Romani Scholars." Critical Romani Studies 1 (1): 8-28.

Mirga-Wójtowicz, Elżbieta. 2013. "Program pomocowy dla społeczności Romów w Polsce - osiągnięcia i wyzwania: Przykład Małopolski” [Assistance program for Roma communities in Poland - achievements and challenges: case of Malopolskie voivodship]. In Studia o Romach $w$ Polsce i w Europie [Studies about Roma in Poland and Europe], edited by Piotr Borek, Kraków: Naukowe Uniwersytet Pedagogiczny.

Morawska, Ewa. 2001. "Structuring Migration: The Case of Polish Income-Seeking Travelers to the West." Theory and Society 30 (1): 47-80.

Morokvasic, Mirjana. 2004. “'Settled in Mobility’: Engendering Post-wall Migration in Europe.” Feminist Review 77 (1): 7-25.

Nacu, Alexandra. 2012. "From Silent Marginality to Spotlight Scapegoating?: A Brief Case Study of France's Policy Towards the Roma." Journal of Ethnic and Migration Studies 38 (8): 1,323-8.

Nagengast, Carole. 1991. Reluctant Socialists, Rural Entrepreneurs: Class, Culture, and the Polish State. Oxford: Westview Press.

Nowicka, Ewa. 2007. "Romowie i świat współczesny" [Roma and the contemporary word]. In Romowie w Polsce i Europie [Roma in Poland and Europe], edited by Piotr Borek, 124-47. Kraków: Naukowe AP.

Nowicka, Ewa, and Maciej Witkowski. 2013. "Nowe możliwości - stare problemy: Przemiany w polityce wobec Romów po 1989 roku i ich społeczne konsekwencje" [New opportunities - old problems: Changes in policy towards Roma after 1989 and its social consequences]. Studia Romologica 6: 97-126.

Okólski, Marek, and John Salt. 2014. "Polish Emigration to the UK after 2004: Why Did So Many Come?" Central and Eastern European Migration Review 3 (2): 11-37.

O’Nions Helen. 2011. “Roma Expulsions and Discrimination: The Elephant in Brussels." European Journal of Migration and Law 13 (4): 361-88.

Oprea, Alexandra. 2004. Re-envisioning Social Justice from the Ground Up: Including the Experiences of Romani Women. Essex Human Rights Review 1 (1): 29-39.

—. 2012. "Romani Feminism in Reactionary Times." Signs: Journal of Women in Culture and Society 38 (1): 11-21.

Piemontese, Stefano, and Tina Magazzini. 2019. Roma Westward Migration in Europe: Rethinking Political, Social, and Methodological Challenges. New York, NY: Springer.

Praszałowicz, Dorota, Krzysztof Makowski, and Andrzej Zięba. 2004. Mechanizmy zamorskich migracji łańcuchowych w XIX wieku: Polacy, Niemcy, Żydzi, Rusini - Zarys problemu [Mechanisms of overseas chain migration in 19th century: Poles, Germans, News, Rusyns - Outline of the problem]. Kraków: Księgarnia Akademicka.

Rakowski, Tomasz. 2009. Łowcy, zbieracze, praktycy niemocy: Etnografia człowieka zdegradowanego [Hunters, gatherers and practitioners of powerlesness: An ethnography of the degraded in postsocialist Poland]. Gdańsk, Poland: Słowo/Obraz Terytoria.

Ryder, Andrew. 2018. "Paradigm Shift and Romani Studies: Research 'on' or 'for' and 'with' the Roma." In Roma Activism: Reimagining Power and Knowledge (Vol. 1), edited by Sam Beck and Ana Ivasiuc. New York, NY: Berghahn Books. 
Scott, James C. 1990. Domination and the Arts of Resistance: Hidden Transcripts. New Haven, CT: Yale University Press.

Sigona, Nando. 2005. “Locating the 'Gypsy Problem.' The Roma in Italy: Stereotyping, Labelling and 'Nomad Camps." Journal of Ethnic and Migration Studies 31 (4): 741-56.

Sigona, Nando, and Nidhi Trehan. 2009. Romani Politics in Contemporary Europe: Poverty, Ethnic Mobilization, and the Neoliberal Order. London: Palgrave Macmillan.

Staniewicz, Teresa. 2011. "Negotiating Space and Contesting Boundaries: The Case of Polish Roma and Polish Migrants - Migration and Adaptation as Viewed via a Social Capital Lens." Studia Migracyjne-Przeglad Polonijny 37.1 (139): 259-89.

Stewart, Michael. 1997. The Time of the Gypsies. Boulder, CO: West View Press.

Stola, Dariusz. 2010. Kraj bez wyjścia?: Migracje z Polski 1949-1989 [Country with no exit?: Migration from Poland 1949-1989]. Warsaw: Instytut Pamięci Narodowej.

Szewczyk, Maciej. 2016. Unia Europejska i Romowie: System wobec kultury etnicznej [European Union and the Roma: System towards the ethnic culture]. Rzeszów-Tarnów, Poland: WSzIiZ w Rzeszowie/Muzeum Okręgowe w Tarnowie.

Talewicz-Kwiatkowska, Joanna. 2013. Wpływ aktywności finansowej Unii Europejskiej na położenie społeczne Romów w Polsce [Influence of the EU financial activity on the Roma social position]. Kraków: Wydawnictwo UJ.

Trumpener, Katie. 1992. “The Time of the Gypsies: A 'People without History' in the Narratives of the West.” Critical Inquiry 18 (4): 843-84.

Turner, Victor, and Edith Turner. 2011. Image and Pilgrimage in Christian Culture. New York, NY: Columbia University Press.

Urbańska, Sylwia. 2015. “Transnational Motherhood and Forced Migration: Causes and Consequences of the Migration of Polish Working-Class Women 1989-2010." Central and Eastern European Migration Review 5(1): 109-28.

van Dijk, Teun A. 2008. Discourse and Power. London: Palgrave Macmillan.

Vermeersch, Peter. 2008. "Exhibiting Multiculturalism: Politicised Representations of the Roma in Poland." Third Text 22 (3): 359-71.

Walaszek, Adam. 1988. Polscy robotnicy, praca i związki zawodowe w Stanach Zjednoczonych Ameryki, $1880-1922$. Wrocław-Warsaw: Ossolineum.

White, Anne, Izabela Grabowska, Paweł Kaczmarczyk, and Krystyna Slany. 2018. The Impact of Migration on Poland: EU Mobility and Social Change. London: UCL Press.

Witkowski, Maciej. 2016. Polityka i antropologia: Praktyki integrowania Bergitka Roma w karpackich wioskach w Polsce [Politics and anthropology: Practices of integrating Bergitka Roma in the Carpathian villages in Poland]. Kraków: Zakład Wydawniczy Nomos.

Zubrzycki, Jerzy. 1988. Soldiers and Pasants: The Sociology of Polish Migration: A Lecture in English and Polish. The Second M. B. Grabowski Memorial Lecture, School of Slavonic and East European Studies. New York, NY: Orbis. 